\title{
Economic growth, labor and productivity in Brazil and the United States: a comparative analysis
}

\author{
ALEXANDRE GORI MAIA \\ ESTHER MENEZES*
}

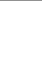

The aim of this paper is to analyze the relation between economic growth and labor market dynamics in Brazil between 1981 and 2009, making a comparison with the United States. Among the findings, one can mention that economic growth in Brazil has been related to a massive incorporation of labor force in labor intensive activities, whereas, in the United States, to a substantial improvement of labor productivity in high-technology activities. Despite the favorable economic context in the 2000s, huge inequalities between these countries have widened since the structure of the Brazilian labor market remained with few or no changes.

Keywords: Brazil; labor productivity; economic growth; labor market.

JEL Classification: J21; J24; J31.
\end{abstract}

\section{INTRODUCTION}

From early 1980 s to the beginning of the $21^{\text {th }}$ century, while the world economy experienced a remarkable increase in prosperity and wealth of the richest nations, several developing economies were hit by successive domestic and international crises. Nevertheless, in the following period (i.e., the 2000s), an extraordinary turnaround in economic outcomes took place in many developing countries. They profited from extremely favorable conditions provided by a long-lasting good performance of world economy, increase in the relative prices of commodities and attraction of capital flows (ECLAC, 2007).

Brazil was one of the main emerging economies especially benefited in this last

\footnotetext{
* Professor, Institute of Economics, State University of Campinas, Unicamp/IE. E-mail: gori@eco. unicamp.br. Economist, State Department of Public Management. E-mail: emenezes@sp.gov.br. Submitted: 19/March/2012; Approved: 16/August/2013.
} 
period. Relevant consequences of the recent dynamics of economic growth in this country were the substantial increase in average wages and reduction in unemployment, inequality and poverty rates (Arbache, 2011; Barros et al., 2011; Nery, 2010). Despite this favorable economic context, Brazil is still characterized by high levels of socioeconomic exclusion and inequality in comparison with other developed and developing countries (UNDP, 2011). Several studies has pointed the low level of productivity and the peripheral development of the Brazilian structure of economic activities as the main sources of its relative low level of socioeconomic development (for example, ECLAC, 2010; Restuccia, 2009).

Therefore, the contrast between Brazilian economic performance in the 2000s and the two previous decades raises relevant questions. For instance, has this exceptional economic performance been based in structural and qualitative changes in the labor market, which would sustain a virtuous trend in the long run? Moreover, have these changes induced substantial reduction in the differences between Brazil and developed countries? In order to discuss these questions, we provide new elements to better understand the relation between economic growth and labor market dynamics in Brazil (complementing previous studies, for example, Ferreira et al., 2011; Cruz et al., 2007; Rocha, 2007), analyzing qualitative and quantitative aspects of the dynamics of growth in this country and how longlasting it would be.

We focus on the contribution of labor market indicators, such as wages, labor productivity and the structure of the economic activities to the dynamics of economic growth between 1981 and 2009. The United States (U.S.) is used as a comparing reference, since they were the fastest one to adopt new technologies, especially technologies of information and communication, which contributed to their high levels of labor productivity (Salvatore, 2008).

In our analysis, the dynamics of economic growth is decomposed in two main sources of variation: employment (labor hours) and labor productivity. We also discuss the contribution of changes in the structure of economic activities to the dynamics of growth, as well to the differences of productivity between these countries. Among the findings one can mention that economic growth in Brazil has been related to a massive incorporation of labor force in labor intensive activities, whereas, in the U.S., to a substantial improvement of labor productivity in high-productivity activities. It means that, in spite of changes in the economic dynamics occurred in the 2000s, by which Brazil was especially benefited, the conditions of important structural variables has remained with few or no changes. Consequently, huge inequalities of wage and productivity between these countries has been widening substantially, which may denote increasing difficulties to Brazil in maintaining a sustainable economic development in the long run, with high productivity, high wages and qualified jobs. 


\section{ECONOMIC GROWTH, PRODUCTIVITY AND WAGES IN BRAZIL AND THE UNITED STATES}

The last quarter of the twentieth century was marked by increasing liberalization of international trade, investment and financial market, which promoted a progressive international economic integration. New technologies were developed, as well as emerging forms of industrial organization and political hegemony (Ocampo, 2003).

In Latin America, this process was preceded by periods of severe inflation, which frightened away domestic and foreign investment and destroyed the potential of economic growth. Since then, inflation management was transformed into a near-obsession and the sensitivity of international financial markets induced their governments to adopt restrictive macroeconomic policies, with negative impacts on economy and employment (Nayyar, 2006).

In the early 1990s, most Latin American countries turned into market-oriented approaches as a way to control hyperinflation, attract foreign direct investment and induce economic development. But ineffective or misguided implementation and conduction of these economic reforms resulted in unsatisfactory economic performance and additional difficulties to improve socioeconomic conditions in these countries. Overall, the 1980s and the 1990s were marked by instability and low economic growth in most Latin American nations (Solimano \& Soto, 2005).

Brazil is one of the biggest developing economies where substantial reforms were implemented. After a period experiencing a huge economic growth of 8.4 percent per year in the 1970s, debt crisis in early 1980s introduced a long period of low and unsteady growth in this country. In the 1990s, Brazil reached success controlling hyperinflation, but its economic dynamics still remained weak for a long period. Besides financial and economic liberalization, restrictive monetary policies, fixed exchange rate, privatizations and other important structural reforms were also applied in order to reach economic stabilization. Some of these policies brought additional difficulties to the Brazilian labor market, contributing to increase unemployment, informality and to constrict real wages growth (BID, 2003). Several international crisis, such as the Mexican crisis in 1994, Asian in 1997 and Russian in 1998 also contributed to the unsatisfactory economic dynamics in Brazil (Galbraith, 2008). This country recovered the potential of economic growth in the 2000s, largely due to increasing prices of commodities and depreciation of its national currency. Indeed, the country showed strength in the last world economic crisis in late $2000 \mathrm{~s}$, exhibiting a better performance than many developed economies.

Meanwhile, the U.S. experienced contradictory dynamics of economic growth. Their most unstable period occurred in the 1970s, when the two oil-price shocks were responsible for periods of severe recessions (Eichengreen, 2004). In that decade, American Gross Domestic Product (GDP) growth was significantly lower than in Brazil (3.7 percent per year). Since then, the U.S. maintained a sustainable economic growth, reaching 3.3 percent per year in the 1980s and 3.4 percent per year in the 1990s, in spite of short periods of economic crises, such as savings and loan 
crisis in the early 1990s and dot com crisis in 2001 (Caldentey et al., 2009). But the financial crises in the late 2000s affected intensively the developed economies, especially the U.S. During the worst periods of the subprime crisis, initiated in 2007 , the economic growth of the main developing countries overcame that of the developed ones.

Although Brazil had success in sustaining a steady economic growth along the 2000s, even after the damaging crisis that took place in 2007, huge structural differences in comparison with developed countries still persist (Restuccia, 2009). The low level of education and infrastructure, as well a productive structure specialized in labor-intensive and low productivity activities have being pointed as the main sources of underdevelopment in Brazil (ECLAC, 2010; Prebisch, 2008). According to Ferreira et al. (2011) total factor productivity has been dropping relatively to the U.S. since early 1980s. Silva and Ferreira (2011) suggest that this trend would be especially due to the decreasing productivity of the service sector. It is also worth highlighting that from the 1970 s to the 1990 s, although industry had a slight productivity growth, the employment grew faster in low-technology-based segments of the transformation industry (Cruz, Nakabashi, Porcile \& Scatolin, 2007), as well in those segments of extractive and transformation industry that usually present low productivity growth (Rocha, 2007).

In order to be sustainable in the long run, economic growth in Brazil requires positive changes in the economic structure, which includes increasing productivity and the participation of high-quality employment. Even though many studies demonstrate strong relationship between the dynamics of GDP and employment, especially in the labor-intensive sectors (Walterskirchen, 1999), labor productivity, which is strictly related to economic growth, is pointed as one of the most important factors to reduce poverty and to improve the standard of living (ILO, 2005). Similar results is found by Hull (2009), whose study about the productivity of economic sectors from different countries also conclude that high productivity sectors contribute more to poverty reduction than the labor-intensive ones, although, according to Walterskirchen (1999), the employment level is more sensitive to the latter.

Labor productivity may be decisive to explain the differences between economic growth in Latin American and in the U.S. in last decades (Restuccia, 2009). Sacconato and Menezes-Filho (2005) suggest that, in the period 1988-1995, productivity was one of the main determinants of differences between income levels in Brazil and in the U.S., as well as between wages in Brazilian high and low productivity sectors. Indeed, many studies (for example, Feldstein, 2008; Salvatore, 2008; Romanatto et al., 2008) found a positive relation between labor productivity and wage, though only a small share of gains from labor productivity may be translated into gains in real wages, as occurred in Brazil in the decades before the 1980s (Colistete, 2009).

In the 2000s, wages increased and unemployment decreased fast in Brazil. In the macroeconomic level, this behavior occurred in a favorable international context, which provided conditions to sustain economic stability and the current account, as well to improve the external debt profile (ECLAC, 2007). Besides the 
dynamics of economic growth, the fall of unemployment and the raise of wages was also result of the Brazilian demographic trend. According to Arbache (2011), the slowdown of working-age population tends to pressure labor supply, whose elasticity decrease if manpower is scarce. In such a context, if productivity is low, high wages could lead to an undesirable side effect: the expansion of production costs, which threaten firms' competitiveness in face of the international competition and, consequently, the maintenance of jobs in the long run.

Overall, the revised literature on productivity, labor market and wages points to a persisting low productivity and low-quality employment in last decades, regardless the better performance of Brazilian economy and income in the 2000s. To check if there are evidences of deeper improvements in Brazilian economic variables that could lead the country to a more persistent social and economic development, in next sections we analyze how divergent from the U.S. is Brazilian labor market structure. We compare the respective labor productivities, wages and the structures of economic activities looking for a converging trend that could indicate further relative qualitative and structural changes in Brazil.

\section{MATERIAL AND METHODS}

\section{Data source}

The comparison between economic dynamics in Brazil and in the U.S. from 1981 to 2009 was based on time series of National Accounts provided by World Data Bank (WDB $)^{1}$ and United Nation Statistical Division (UNSD) $)^{2}$. We also used labor market information provided by microdata of PNAD (Pesquisa Nacional por Amostra de Domicílios), sponsored by IBGE (Instituto Brasileiro de Geografia e Estatística), and microdata of CPS (Current Population Survey), sponsored by BLS (Bureau of Labor Statistics) ${ }^{3}$.

The dynamics of Gross Value Added (GVA) and wages among economic activities allowed us to analyze the development of the economy and labor market in Brazil and in the United States. However, wages and GVA may not be directly comparable in a specific point in time, since they are based on distinct methodologies. Differences may be more expressive in Brazil, where wages are based on

\footnotetext{
${ }^{1}$ Available at http://databank.worldbank.org. Access on March 2011.

${ }^{2}$ Available at http://unstats.un.org. Access on March 2011.

${ }^{3}$ In both surveys, employed has been considered that with 16 years of age or older who, during the reference week (a) did any work at all (for at least 1 hour) as paid employee; worked in his own businesses, profession, or on his own farm; or worked 15 hours or more as unpaid worker in an enterprise operated by a family member or (b) was not working, but who had a job or business from which he was temporarily absent (BLS, 2002). Unemployed has been considered that who was not employed during the reference week and had made specific efforts to find an employment some time during the 4-week period ending with the reference week.
} 
monthly estimates (in the U.S. they are yearly estimates), which may be subjected to seasonality and periods of high volatility.

Brazilian and American nominal wages were deflated to constant values of July 2009 using the INPC (Índice Nacional de Preços ao Consumidor) in Brazil and the CPI (Consumer Price Index) in the U.S. Subsequently, Brazilian wages were converted to PPP (Purchasing Power Parity) dollars based on the conversion factor provided by WDB ${ }^{4}$. Similar procedures were adopted to convert current values of GVA to PPP values of July 2009: using first the GDP deflator and second, just for Brazil, the PPP conversion factor. PPP is both a currency convertor and a spatial price deflator. Despite some limitations that may exist in this process of conversion (see, for example, Taylor, 2003), it has been widely used in international comparative studies, providing a useful measure that minimizes differences in the purchase parity among countries based on the differences in their price levels (OECD, 2012; ILO, 2005).

Economic activities were classified according to the main groups suggested by the UNSD: i) Agriculture, hunting, forestry and fishing; ii) mining, manufacturing and utilities (electricity, gas and water supply); iii) construction; iv) wholesale, retail trade, restaurants and hotels; v) transport, storage and communication; vi) other activities (financial intermédiation, real state, renting, business activities, public administration, defense, education, health, social work, social services, personal activities, private households and others services).

\section{Decomposing economic growth}

Economic growth was decomposed in two main sources of variation: labor hours (employment) and labor productivity. Whatever a result of diverse factors (i.e., investment in infrastructure, education levels of population, institutional environment and public policies) or a determinant of economic growth (as discussed in earlier section), labor productivity is used in our study as a comprehensive summary of the structural characteristics observed in Brazil and in the U.S. Although labor productivity only partially reflects the personal capacities of workers and the intensity of their efforts, it sheds light on how efficiently labor is combined with the other factors of production (OECD, 2001). Labor productivity is relatively easy to measure, is a key determinant of the living standards, since it indicates the potential of wealth creation, and is one of the most used indicators in international comparative studies (Ark, 1996).

We used the GDP and the GVA by economic activity to evaluate the dynamics of the economic growth. Since the GVA is the product between labor hours $(L$, in h) and labor productivity $(P$, in US $\$ / h)$, its variation in a specific period of time $\left(\mathrm{D}^{t}\right)$ can be expressed by:

$$
\Delta^{t} G V A=\Delta^{t} L \times P=\bar{P}_{t} \Delta^{t} L+\bar{L}_{t} \Delta^{t} P
$$

\footnotetext{
${ }^{4}$ Brazilian Reais (R\$) of July 2009 were multiplied by 1.2862 in order be converted to PPP dollars.
} 
Where $\bar{P}_{t}$ is the average productivity in the period $t$ and $\bar{L}_{t}$, the respective average labor hours. The first term $\left(\bar{P}_{t} \Delta^{t} L_{i}\right)$ measures the impact of employment on economic growth and the second $\left(\bar{L}_{t} \Delta^{t} P_{i}\right)$, the impact of labor productivity.

We can also consider the contribution of each economic sector to economic growth. Suppose the variation in the GVA as a sum of the variation observed in each of the $k$ economic sectors:

$$
\Delta^{t} G V A=\sum_{i=1}^{k} \Delta^{t} G V A_{i}
$$

From expressions (1) and (2) we have:

$$
\Delta^{t} G V A=\sum_{i=1}^{k} \Delta^{t} L_{i} P_{i}=\sum_{i=1}^{k}\left(\bar{P}_{t} \Delta^{t} L_{i}+\bar{L}_{t} \Delta^{t} P_{i}\right)
$$

The first term $\left(\bar{P}_{t} \Delta^{t} L_{i}\right)$ measures the contribution of the labor force in the $i$-th economic activity to economic growth, as well the second term $\left(\bar{L}_{t} \Delta^{t} P_{i}\right)$ measures the impact of the productivity of the $i$-th economic activity on total growth.

\section{Decomposing differences of labor productivity}

Differences between American and Brazilian productivities were also decomposed in two main sources: i) productivity effect; ii) composition effect. First, suppose the difference between American and Brazilian productivity $\left(\Delta^{c} P\right)$ as a weighted average of the differences of productivity observed in each economic sector:

$$
\Delta^{c} P=\sum_{i=1}^{k} \Delta^{c} p_{i} \bar{P}_{c_{i}}
$$

Where $\Delta^{c} p_{i}$ is the difference between American and Brazilian shares of the $i$-th economic activity in their respective GVA and $\bar{P}_{c_{i}}$, the average productivity observed in Brazil and in the U.S. for the $i$-th economic activity. Making the necessary transformations, equation (4) is the same that:

$$
\Delta^{c} P=\sum_{i=1}^{k}\left[\Delta^{c} p_{i}\left(\bar{P}_{c_{i}}-\bar{P}_{c}\right)+\bar{p}_{i} \Delta^{c} P_{i}\right]
$$

Where $\bar{P}_{c}$ is the average total productivity observed in Brazil and the U.S. The first term of equation (5) represents the composition effect and measures the contribution of differences between economic structures in Brazil and in the U.S. to the overall difference of productivity. For example, how the higher participation of low productivity sectors in Brazil help explaining its lower total productivity in comparison with the U.S. The second term represents the productivity effect and measures the contribution of differences of productivities between similar economic activities in Brazil and the U.S. For example, the contribution of the lower productivities in the Brazilian economic sectors in comparison with equivalent sectors in the U.S. 


\section{RESULTS}

\section{Economic and labor market dynamics}

Brazilian and American economic growth presented distinct trends between 1981 and 2009 (Table 1)

After two decades of low economic growth, the Brazilian GDP grew 3.4 percent per year between 2001 and 2007. Even in the context of an international crisis beginning in 2007, the GDP grew, on average, 2.4 percent per year in 2008 and 2009. In the U.S., economic growth was higher in the 1980s and in the 1990s and was specially affected by the financial crises in 2007. In 2008 and 2009, the U.S. witnessed an average negative growth of 1.3 percent per year. On balance, the difference between American and Brazilian cumulative GDP growth in the period was relatively low: only 7.5 percentage points.

Table 1: Annual and cumulative growth of Gross Domestic Product and Economically Active Population - Brazil and the U.S., 1981 to 2009

\begin{tabular}{ccccccccc}
\hline \multirow{2}{*}{ Period } & \multicolumn{4}{c}{ GDP } & \multicolumn{2}{c}{ Erazil } & \multicolumn{2}{c}{ GDP } \\
& Annual & Cumul & Annual & Cumul & Annual & Cumul & Annual & Cumul \\
\hline $81-90$ & 2.2 & 21.9 & 3.3 & 33.4 & 3.3 & 34.0 & 1.5 & 14.5 \\
$91-00$ & 2.5 & 56.7 & 2.7 & 74.6 & 3.4 & 87.7 & 1.3 & 30.4 \\
$01-07$ & 3.4 & 98.2 & 2.5 & 108.0 & 2.4 & 121.3 & 1.1 & 41.1 \\
$08-09$ & 2.4 & 108.0 & 2.1 & 116.8 & -1.3 & 115.5 & 0.2 & 41.6 \\
\hline
\end{tabular}

Source: Based on data from WDB, CPS and PNAD.

Nevertheless, the differences between the dynamics of labor market in these countries are remarkable. From 1981 to 2009, Economically Active Population (EAP) in Brazil increased 117 percent, 9 percentage points above its cumulative economic growth. In the U.S., it increased just 42 percent, 74 percentage points under their accumulated economic growth. In fact, the extreme differences between the growth of economy and labor force in Brazil may have contributed to the explosive unemployment in the 1990s (Figure 1). Between 1981 and 2000, period of low economic growth in this country, the cumulative growth of its EAP was 18 percentage points higher than the GDP one, and the unemployment reached 11 percent of the EAP in 1999. On the other hand, high economic growth in the 2000s and reduction in the demand for jobs were some of the main responsible for the decline of the unemployment rate in the 2000s. Brazilian EAP has fallen since the 1980s. In the U.S., the low EAP growth in the 1980s and 1990s contributed to maintain low unemployment rates in a context of high increases of productivity. But the downturn in economic activity in 2007 affected significantly the American labor force, increasing unemployment rate to 8.8, the highest value since 1984 . 
Figure 1: Unemployment rate (\% of EAP) - Brazil and the U.S., 1981 to 2009

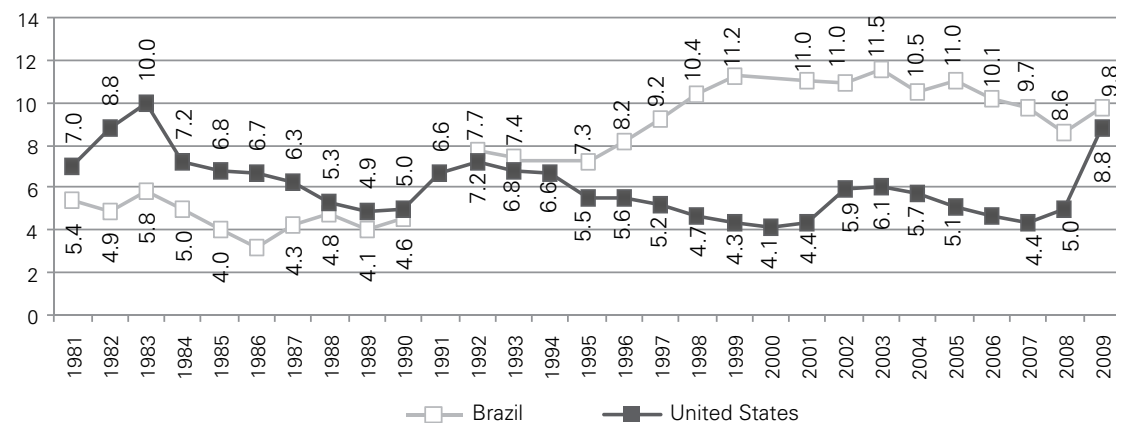

Source: Based on data from CPS and PNAD.

The trajectory of labor productivities, given by the ratio between GVA and labor hours, also highlights how American good economic performance was achieved with low increase of labor force supply and substantial improvement of labor productivity (Figure 2). While the labor productivity in the U.S. grew 50 percent between 1981 and 2009, it grew just 17 percent in Brazil in the same period.

Figure 2: Labor productivity (GVA US\$ / labor hour) and average wage (US\$ / labor hour) - Brazil and the U.S., 1981 to 2009

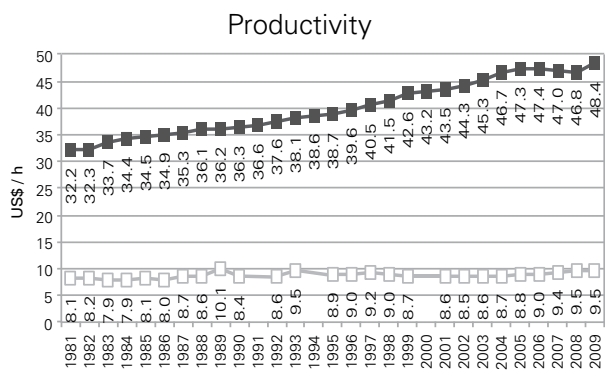

$-\square-$ Brazil
Wage

Values at constant prices of July 2009 - US\$ PPP

Source: Based on data from UNSD, CPS and PNAD.

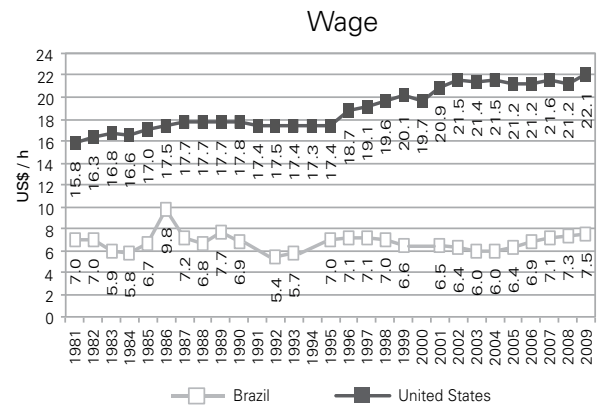

Gains in American labor productivity gave opportunity to increase real wages in 40 percent between 1981 and 2009. Indeed, many studies found a positive relation between labor productivity and wages (Hull, 2009; Millea, 2002; Feldstein 2008; Salvatore, 2008) and the results shown in Figure 2 indicate a stronger relation between these variables in the U.S. In Brazil, some cases of opposite trends in this relation occurred, for instance, during the unstable periods of economic reforms, in the mid-1980s and early 1990s (e.g., in 1984 and 1993). Overall, average wage in Brazil grew only 7 percent between 1981 and 2009, 10 percentage points less than the labor productivity, and in the whole period, the ratio between American and Brazilian average wages rose from 2.2 in 1981 to 2.9 in 2009. 
Furthermore, since 2005 real wages has grown faster than labor productivity in Brazil, which can be especially attributed to increasing rates of formalization in the labor market, successive adjustments and appreciations of the minimum wage (Saboia, 2010), as well to decreasing supply of skilled labor force (Arbache, 2011). Between 2005 and 2009, average wage grew 17 percent in Brazil, 9 percentage points higher than labor productivity.

The contribution of employment and labor productivity to economic growth in both countries can be evaluated using equation (1). In Table 2 , the decomposed variation of the GVA reveals, for example, that only 31 percent (US\$ 105 billion) of the total Brazilian GVA variation of US\$ 337.5 billion between 2000 and 2007 was due to increasing productivity. The higher share of this growth (69 percent) was due to increasing participation of labor force. In spite of the remarkable rise of the productivity share in the Brazilian economic growth between 1981 and 2009 (from 15 percent in the 1980s to 30 percent in the years 2000), huge differences remain in comparison with the American dynamics: in the U.S., more than 50 percent of the economic growth in the 1990s and in the 2000s (before economic crises) was due to increasing productivity.

Table 2: Sources of variation in the Gross Value Added: employment (Emp.) and labor productivity (Prod.) - Brazil and the U.S., 1981 to 2009

\begin{tabular}{|c|c|c|c|c|c|c|c|}
\hline & \multirow{2}{*}{ Period } & \multicolumn{3}{|c|}{ US\$ (1) } & \multicolumn{3}{|c|}{ Row \% } \\
\hline & & Emp. & Prod. & Total & Emp. & Prod. & Total \\
\hline \multirow{4}{*}{$\begin{array}{l}\overline{\bar{N}} \\
\overline{\mathbb{N}} \\
\bar{\infty}\end{array}$} & $81-90$ & 224.9 & 38.5 & 263.4 & 85.4 & 14.6 & 100.0 \\
\hline & $90-00$ & 209.0 & 46.6 & 255.6 & 81.8 & 18.2 & 100.0 \\
\hline & $00-07$ & 232.2 & 105.3 & 337.5 & 68.8 & 31.2 & 100.0 \\
\hline & 07-09 & 56.0 & 23.1 & 79.1 & 70.8 & 29.2 & 100.0 \\
\hline \multirow{4}{*}{$\stackrel{\sim}{\supset}$} & $81-90$ & $1,301.7$ & 891.8 & $2,193.5$ & 59.3 & 40.7 & 100.0 \\
\hline & $90-00$ & $1,592.9$ & $1,812.1$ & $3,405.0$ & 46.8 & 53.2 & 100.0 \\
\hline & $00-07$ & 927.5 & $1,111.1$ & $2,038.6$ & 45.5 & 54.5 & 100.0 \\
\hline & 07-09 & -765.6 & 394.3 & -371.3 & 206.2 & -106.2 & 100.0 \\
\hline
\end{tabular}

(1) Values at constant prices of July 2009 - US\$ PPP

Source: Based on data from UNSD, CPS and PNAD.

Overall, results suggest that the U.S. were successful in searching other sources of economic growth: the substantial improvement of American labor productivity may have mitigated the drawback effects of a low labor force supply and hence reinforcing economic growth. On the other hand, Brazil fought against a restricted economic growth with a substantial increase of its labor force and a relatively low productivity for a long period, which may explain the high unemployment rates and low wages witnessed in most of the period analyzed. 


\section{Structure of economic activities}

Both Brazil and the U.S. presented substantial changes in their structure of economic activities (Table 3). The most expressive change in Brazil was the sharp reduction of the agricultural labor force, from 27 percent in 1981 to 12 percent in 2009 , as a result of the adoption of new agricultural technologies and the rural exodus. In the same period, the share of agricultural production on GVA fell just 2 percentage points. Regarding manufacturing activities, economic liberalization and the appreciation of the Brazilian currency can be pointed as one of the main responsible for the slight reduction of this sector in the share of labor force (from 17 in 1981 to 15 percent in 2009) and, more intensively, in the share of the total GVA (from 29 percent in 1981 to 20 percent in 2009).

Table 3: Distribution of employment and GVA according to economic activities - Brazil and the U.S., 1981 and 2009

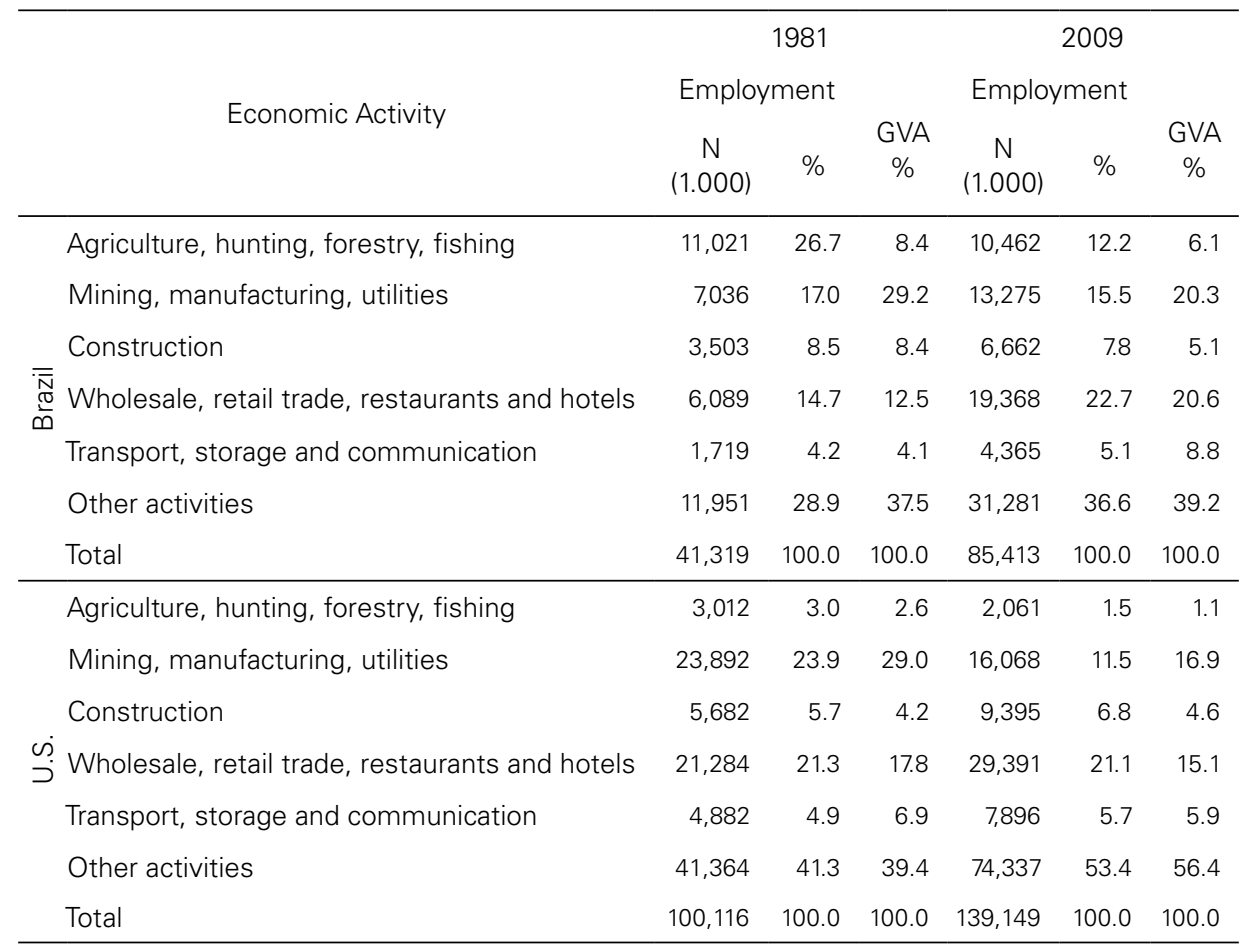

Source: Based on data from UNSD, CPS and PNAD.

In the U.S. the reduction of the manufacturing labor force was more intense, from 24 to 12 percent between 1981 and 2009 . These results may suggest that the transition from the manufacturing-based economy to a service-based one was substantially more advanced in this country, where more than 80 percent of the working force were employed in service activities in 2009. Differences between Brazilian and American stages of development are even stronger if we consider that the 
growth of labor productivity and average wages in the U.S. was specially high in the service sector that mostly accumulate jobs and GVA: other activities (which considers, for instance, financial, real state, renting and public administration sector), where labor productivity grew 62 percent and average wages grew 51 percent (Table 4).

Indeed, besides huge differences in the distribution of economic activities, labor productivity and average wages are substantially higher in the U.S. for all economic sectors. Differences between American and Brazilian labor productivities rose in most sectors (exception for agricultural, transport, storage and communication) and the high inequalities between these countries were still larger in 2009. Overall, the ratio between the American and Brazilian labor productivities rose from 4 to 5 between 1981 and 2009, and the ratio between the average wages rose from 2 to 3. One of the most expressive differences was observed in the agriculture sector, where the American labor productivity was almost 7 times higher than the Brazilian one in 2009, and the average wage was 3 times higher.

Table 4: Labor productivity (GVA US\$ PPP/h) and average monthly wage (US\$ PPP) - Brazil and the U.S., 1981 and 2009

\begin{tabular}{|c|c|c|c|c|c|}
\hline & \multirow[b]{2}{*}{ Economic Activity } & \multicolumn{2}{|c|}{1981} & \multicolumn{2}{|c|}{2009} \\
\hline & & GVA & Wage & GVA & Wage \\
\hline \multirow{7}{*}{$\begin{array}{l}\overline{\bar{N}} \\
\frac{\mathbb{0}}{\omega} \\
\overline{0}\end{array}$} & Agriculture, hunting, forestry, fishing & 2.5 & 3.9 & 4.8 & 3.8 \\
\hline & Mining, manufacturing, utilities & 13.5 & 9.2 & 12.1 & 7.8 \\
\hline & Construction & 7.8 & 5.4 & 5.8 & 5.9 \\
\hline & $\begin{array}{l}\text { Wholesale, retail trade, restaurants } \\
\text { and hotels }\end{array}$ & 6.4 & 6.6 & 8.1 & 6.3 \\
\hline & Transport, storage and communication & 7.1 & 8.7 & 14.4 & 8.3 \\
\hline & Other activities & 11.7 & 8.5 & 11.1 & 9.8 \\
\hline & Total & 8.1 & 7.0 & 9.5 & 7.5 \\
\hline \multirow{7}{*}{$\stackrel{\sim}{\supset}$} & Agriculture, hunting, forestry, fishing & 24.0 & 4.5 & 31.9 & 9.7 \\
\hline & Mining, manufacturing, utilities & 37.0 & 18.3 & 65.8 & 25.1 \\
\hline & Construction & 23.2 & 17.1 & 32.0 & 21.0 \\
\hline & $\begin{array}{l}\text { Wholesale, retail trade, restaurants } \\
\text { and hotels }\end{array}$ & 28.4 & 13.0 & 36.6 & 16.5 \\
\hline & Transport, storage and communication & 43.3 & 19.6 & 46.7 & 22.0 \\
\hline & Other activities & 31.8 & 15.9 & 51.6 & 24.0 \\
\hline & Total & 32.2 & 15.8 & 48.4 & 22.1 \\
\hline
\end{tabular}

Values at constant prices of July 2009 - US\$ PPP

Source: Based on data from UNSD, CPS and PNAD.

Results presented in Table 5 represent the decomposition of the total differences between American and Brazilian productivities in two main sources of variation (equation 5): i) productivity effect; ii) composition effect. Results highlight that 
differences of productivities in similar economic activities represent the most expressive share of the total inequality between American and Brazilian economies. Overall, 98 percent of the total differences of productivities between Brazil and the U.S. in 2009 were due to different patterns of productivity for similar economic activities. This means that, if Brazil and the U.S. had similar share of economic activities in the total GVA, 98 percent of the difference between their total productivity would still persist. The most expressive changes in this pattern of inequality between 1981 and 2009 were the fall of differences for traditional activities (such as agricultural, mining and manufacturing) and the substantial rise of differences for some of the most productivity activities, such as financial, real state, renting and public administration (other activities).

Table 5: The contribution (\%) of composition (Comp.) and productivity (Prod.) effects to the total inequality between American and Brazilian productivities - 1981 and 2009

\begin{tabular}{lrrrrrr}
\hline \multicolumn{1}{c}{ Economic Sector } & \multicolumn{3}{c}{1981} & \multicolumn{3}{c}{2009} \\
& Comp. & Prod. & Total & Comp. & Prod. & Total \\
\hline Agriculture, hunting, forestry, fishing & 1.7 & 5.2 & 7.0 & 1.3 & 2.4 & 3.7 \\
Mining, manufacturing, utilities & -0.1 & 30.2 & 30.1 & -0.9 & 25.0 & 24.1 \\
Construction & 0.8 & 4.3 & 5.1 & 0.1 & 3.2 & 3.3 \\
Wholesale, retail trade, restaurants and hotels & -0.6 & 14.7 & 14.1 & 0.9 & 12.7 & 13.6 \\
Transport, storage and communication & 0.6 & 8.8 & 9.5 & -0.1 & 5.9 & 5.8 \\
Other activities & 0.1 & 34.0 & 34.2 & 1.0 & 48.4 & 49.5 \\
Total & 2.7 & 97.3 & 100.0 & 2.4 & 97.6 & 100.0 \\
\hline
\end{tabular}

Source: Based on data from UNSD, PNAD and CPS.

Finally, we can also analyze the contribution of each economic sector to the dynamics of economic growth in Brazil and in the U.S. (equation 3). Table 6 shows the contribution of employment and labor productivity in each sector $(\%)$ to the total variation in the GVAs between 1981 and 2009. Results reveal that, in the whole period, $78 \%$ of the total variation in the Brazilian GVA was due to increasing labor force participation. This means that economic growth in Brazil was basically achieved with massive incorporation of labor force, largely due to increasing participation of low-wage and low-productivity service activities, such as wholesale, retail trade, restaurants, and hotels. For example, 22 percent of GVA growth in Brazil was due to increasing participation of labor force in these activities, which present the third lower average wage and productivity in the Brazilian economic structure. But the most expressive contribution was given by other service activities, which present the high share of total GVA in Brazil.

On the other hand, economic growth in the U.S. was mainly achieved with labor productivity. Overall, 54 percent of the American economic growth was due to increasing labor productivity, especially in high-wage and high-productivity activities. For example, the increasing productivity in services such as financial inter- 
médiation, real state, renting and business activities (other activities), which present the second higher wage and productivity in the U.S., was responsible for 32 percent of the GVA growth in this country.

Table 6: The share of employment and labor productivity to total economic growth (\%) - Brazil and the U.S., 1981 and 2009

\begin{tabular}{lrrr}
\hline \multicolumn{1}{c}{ Economic Sector } & Employment & Productivity & Total \\
\hline Agriculture, hunting, forestry, fishing & -2.1 & 6.2 & 4.1 \\
Mining, manufacturing, utilities & 16.2 & -3.4 & 12.7 \\
Construction & 4.8 & -2.5 & 2.3 \\
$\overline{\bar{N}}$ Wholesale, retail trade, restaurants and hotels & 22.0 & 5.4 & 27.4 \\
$\overline{\frac{0}{\omega} \text { Transport, storage and communication }}$ & 6.8 & 5.9 & 12.7 \\
Other activities & 43.6 & -2.9 & 40.7 \\
Total & 78.2 & 21.8 & 100.0 \\
\hline Agriculture, hunting, forestry, fishing & -0.9 & 0.7 & -0.3 \\
Mining, manufacturing, utilities & -11.0 & 17.1 & 6.1 \\
Construction & 3.1 & 1.9 & 5.0 \\
W.j. & 7.1 & 5.5 & 12.6 \\
Transportesale, retail trade, restaurants and hotels & 4.3 & 0.6 & 4.9 \\
Other activities & 40.1 & 31.6 & 71.7 \\
Total & 45.8 & 54.2 & 100.0 \\
\hline
\end{tabular}

Source: Based on data from UNSD, CPS and PNAD.

\section{DISCUSSION}

In the previous sections we analyzed in what extent qualitative or structural changes were linked to economic growth and the improvement of the labor market indicators in Brazil between 1981 and 2009, making a comparison with the U.S., a frontier economy. In the 2000s, Brazilian economy grew faster than EAP, substantially increasing average wages and reducing unemployment rates. Besides higher economic growth, other important factors affected the dynamics of labor market in this period. For instance, the working-age population in Brazil is experiencing a fast aging, reducing the demand for jobs (Arbache, 2011). Moreover, the substantial valorization of the minimum wage impacted on the income distribution, increasing average wages and reducing inequalities (Barros et al., 2011; Nery, 2010). But Brazilian labor productivity, the main factor for a sustainable variation in wages, grew slowly.

Labor productivity plays a fundamental role in the dynamics of the economy and labor market, as well has been pointed as closely related to the peripheral stage 
of socioeconomic development in Brazil. Overall, results are not satisfactory for this country, where labor productivity grew slightly in three decades and huge differences in relation to the U.S. have worsened. The relation between labor productivity and average wages are stronger in the U.S., where, in the whole period, gains in productivity meant higher increases in the average wages. In the 1980s and in the 1990s, Brazil witnessed periods of economic instability and contradictory trends between productivity and wages. The most unstable period was in the early 1990s, when Brazil underwent intense economic reforms (see Netto \& Curado, 2005). In this period, productivity increased and average wage decreased. On the other hand, in the 2000s productivity grew faster than average wages, which can be partially attributed to the appreciation of the minimum wage and to an increasing formalization in the labor market (Saboia, 2010). Such huge differences between labor productivities help explaining why average wages in Brazil are substantially lower than in the U.S. Such contrasts are even more evidenced by differences between similar economic activities.

It is worth to mention some issues about what is in the root of such differences. American technological progress has been achieved as a result of innovations and better use of information and communication technologies, based on the rise of the New Economy (Salvatore, 2008), which, in turn, benefited the export-services sector. According to Yotopoulos and Sawada (1999), although comparative advantage in the production of commodities still respond to an important role in world trade, trade in services grew substantially and nowadays it represents more than 20 percent of total international trade. Relative advantages related to reputation, customization, trust and infrastructure give special advantage to developed countries in this trade competition. Services exported by the U.S. are not easily accessible to developing countries. A complex range of public infrastructure that allow such specialization usually comes at high investment costs, which is related to: technical education infrastructure, in the form of technology and biotechnology parks, high speed fiber optics communication, networks that make possible the instantaneous transmission of data, and, especially, an army of well-trained workers.

On the other hand, Brazil seemed remaining specialist in labor-intensive activities in such a way that, in the whole period, the ratio between American and Brazilian labor productivity shifted from 4 (in 1981) to 5 (2009). In contrast to the U.S. productivity, which has grown especially in high-productivity service activities, Brazilian labor productivity grew faster in labor-intensive sectors, such as agriculture and transport. Such findings meet those of Ferreira et al. (2011), who similarly found divergent trend in American and Brazilian total factor productivity since early 1980s. Other authors (Cruz et al., 2007; Rocha, 2007) also mention the employment trend towards low-technology and low-productivity segments of the industry in the 1980s and 1990s, which may have persisted in the industry and service activities over the 2000s. These results may also sustain the evaluation of Ocampo (2003), who, based on the sharp reduction of manufacturing activities in developing countries, argues that these countries had not achieved an equivalent stage of 
development and competitiveness of the richest nations and had blocked up the same trajectory of development made by all industrialized countries until then.

As Reinert (2003) argued, these results would suggest that U.S. is focusing in producing continuous flows of innovations that give opportunity to raise their real wages. In turn, Brazil would be specializing either in economic activities where there is very little or no technological change, or where they take the form of incremental and process innovations, in which technical change is taken out in the form of lower prices to the consumer rather than in higher wages to the workers, who are typically unskilled.

\section{CONCLUSION}

Labor productivity is not the only variable to determine, or be affected by, the interactions between labor market and economic growth. However, it plays an important role in such dynamics and is extremely relevant to explain or summarize the structural differences of development among economies. It is especially relevant to compare so different economies as Brazil and the U.S., whose economic growth trajectories could lead to simplistic conclusions if not analyzed precisely. According to the analyses presented in this paper, economic growth in Brazil seems to remain based especially on an intense absorption of workers in the labor market rather than profound structural changes (in both general and sectoral labor productivity trends), which surely brings positive results in the short run. Nevertheless, if compared to a frontier economy, as the U.S., instead of a convergence of wages (towards factor-price equalization), one notices a substantial increase of inequalities between Brazilian and American labor market.

Although Brazil has been successful in maintaining economic growth in the 2000s (even after the 2007 world economic crisis), the country has not presented substantial qualitative changes in its productive sector, as demonstrated by its poor labor productivity rates, as well by its patterns of sector participation and labor allocation. Several factors that contribute to configure labor productivity can help explaining the low level of productivity in Brazil in comparison with the U.S. For instance, Restuccia (2009) highlights how Latin American countries have been characterized by institutions and policy distortions, such as high costs to start a business, barriers to formal market entry and different forms of regulations, which many times misallocated resources across plants and shifted the distribution of plants to lower productivity levels. The low level of investment in innovation and technology is another frequently mentioned factor influencing productivity in Brazil (ECLAC, 2010) as well as the level and quality of the working force education (Ferreira et al., 2011).

The persistent differences between Brazilian and American labor markets showed that not only high economic growth is needed to improve its marginal stage of development and to maintain a sustainable growth in the long run. Brazil has to improve substantially its productivity in order to maintain the gains achieved in 
last years and to reach even better results in the effort to generate high-quality jobs, one of the main conditions to improve the structure of the labor market and to increase real wages, therefore reducing inequalities in comparison with developed countries. Moreover, Brazilian EAP is reducing sharply, which may imposes serious constraints on the long-run if economic growth in this country remains dependent on the rise of labor-intensive activities.

Average wages in Brazil grew substantially in the years 2000, but there is a natural and low limit to raise wages in a context of very poor productivity. Labor productivity in Brazil is very low in all economic sectors, and this is the main responsible for the huge total inequality compared to the U.S. To sum up, in order to improve labor market conditions, Brazil would improve labor productivity in all economic sectors rather than just moving from a primary-based to a service-based economy (which is already a reality).

\section{REFERENCES}

Arbache, J. (2011) “Transformação demográfica e competitividade internacional da economia brasileira”. Revista do BNDES (36), 365-392.

Ark, B. v. (1996) "Issues in measurement and international comparison issues of productivity - an overview", Industry Productivity: International Comparison and Measurement Issues, OECD, October.

Barros, R. P., Carvalho, M. d., Franco, S., Mendonça, R., and Rosalém, A. (2011) "Sobre a evolução recente da pobreza e da desigualdade no Brasil”, in J. A. Castro and F. M. Vaz, Situação Social Brasileira: Monitoramento das Condições de Vida 1 (pp. 41-64). Brasília: IPEA.

BID (2003) Procuram-se Bons Empregos: O Mercado de Trabalho na América Latina. BID.

Caldentey, E. P., Titelman, D., and Pineda, R. (2000) The Current Global Financial Crisis: What Was Really 'Purely Prime'? Santiago: ECLAC.

Colistete, R. P. (2009) “Salários, produtividade e lucros na indústria brasileira, 1945-1978”, Revista de Economia Política, 29 (4), 386-405.

Cruz, M. J., Nakabashi, L., Porcile, G., and Scatolin, F. D. (2007) "Uma análise do impacto da composição ocupacional sobre o crescimento da economia brasileira”. Economia, Selecta, 8 (4), 55-73.

ECLAC (2010) "Heterogeneidad estructural y brechas de productividad: de la fragmentación a la convergencia”. In ECLAC, La Hora de la Igualdad: Brechas por Cerrar, Caminos por Abrir (pp. 91-130). Santiago: ECLAC.

ECLAC (2007) "Reflexiones sobre el crecimiento económico de América Latina y el Caribe", In ECLAC, Estudio Económico de América Latina y el Caribe 2006-2007 (pp. 95-108). Santiago: Comisión Económica para América Latina y el Caribe.

Eichengreen, B. (2004) Capital flows and crises. Cambridge: MIT Press.

Feldstein, M. (2008) “Did wages reflect growth in productivity?”, Journal of Policy Modeling, 30 (4), 591-594.

Ferreira, P. C., Pessôa, S. d., and Veloso, F. A. (2011) “On the evolution of TFP in Latin America”, Ensaios Econômicos (Working Papers). Rio de Janeiro: FGV, EPG.

Galbraith, J. (2008) "Inequality and economic and political changes". UTIP Working Paper, 51. Austin: University of Texas.

Hull, K. (2009) "Understanding the relationship between economic growth, employment and poverty reduction", in OECD, Promoting Pro-Poor Growth: Employment (pp. 69-94).

ILO (2005) World Employment Report 2004-2005: Employment, productivity and poverty reduction. Geneva: International Labour Organization. 
Millea, M. (2002) "Disentangling the wage-productivity relationship: evidence from select OECD member countries", in (OECD, ed.) International Advances in Economic Research, 8 (4), 314-323.

Nayyar, D. (2006) "Globalisation, history and development: a tale of two centuries", Cambridge Journal of Economics, 30 (1), 137-159.

Nery, M. (2010) The New Middle Class in Brazil: The Bright Side of the Poor. Rio de Janeiro: FGV/ IBRE, CPS. Retrieved in from http://www.fgv.br/cps/nmc/, in 2012.

Netto, C. R., and Curado, M. L. (2005) "Produtividade do trabalho, salários reais e desemprego na indústria de transformação do Brasil na década de 1990”, Revista de Economia Contemporânea, 9 (3), 485-508.

Ocampo, J. A. (2003) "Development and the global order:, in H-J. Chang, Rethinking Development Economics (pp. 83-104). London: Anthem Press.

OECD (2012) Eurostat-OECD methodological manual on purchasing power parities. Luxembourg: Publications Office of the European Union, 2012.

OECD (2001) Measuring Productivity: Measurement of aggregate and industry-level productivity growth. OECD.

Prebisch, R. (1981) The Latin American periphery in the global system of capitalism”, CEPAL Review, 13, 143-150.

Prebisch, R. (2008) “Hacia una teoria de la transformación”, Revista CEPAL (96), 27-71.

Reinert, E. (2003) "Increasing poverty in a globalized world: Marshal Plans and Morgenthau Plans as mechanisms of polarization of world incomes", in H-J. Chang, Rethinking Development Economics. London: Anthem Press.

Restuccia, D. (2009) The Latin American Development Problem. Santiago de Chile: CEPAL.

Rocha, F. (2007) "Produtividade do trabalho e mudança estrutural nas indústrias brasileiras extrativa e de transformação, 1970-2001”, Revista de Economia Política, 27 (2), 221-241.

Romanatto, E., Porcile, G., and Curado, M. (2008) "Produtividade, salários e taxa de câmbio: uma análise da experiência brasileira nos anos 1990”, Revista de Economia Contemporânea, 12 (3), 545-570.

Saboia, J. (2010) "Elasticidades dos rendimentos do trabalho em relação ao salário mínimo: a experiência de um período recente de crescimento do salário mínimo”, Economia e Sociedade, 19 (2), 359-380.

Sacconato, A. L., and Menezes-Filho, N. A. (2005) "O que explica a diferença de rendimentos entre trabalhadores americanos e brasileiros? uma análise com microdados", Pesquisa e Planejamento Econômico, 35 (3), 333-354.

Salvatore, D. (2008) "Growth, productivity and compensation in the United States and in the other G-7 countries", Journal of Policy Modeling, 30, 627-631.

Solimano, A., and Soto, R. (2005) "Economic growth in Latin America in the late 20th century: evidence and interpretation", CEPAL Serie Macroeconomía Del Desarrollo, 33. Santiago: ECLAC.

Taylor, M. P. (2003) "Purchasing power parity", Review of International Economics, 436-452.

UNDP (2011) Human Development Report 2011 - Sustainability and Equity: a better future for all. New York: United Nations Development Programme.

Walterskirchen, E. (1999) The relationship between growth, employment and unemployment in the EU. European Economists for an Alternative Economic Policy - TSER Network, Workshop. Barcelona: WIPO - Austrian Institute of Economic Research.

Yotopoulos, P. A., and Sawada, Y. (1999) "Free currency markets, financial crises and the growth debacle: is there a causal relationship?”, SIEPR Discussion Paper, 99-004. Stanford Institute for Economic Policy Research. 